\title{
JURY TRIAL AND MR. JUSTICE BLACK
}

\section{LEON GREEH†}

JURY trial, like so many other institutions of Anglo-American law, has an intricate history which cannot be captured in a few words. It has never remained the same long enough so it could be said, "This is it, simon-pure." Transplanted to a new environment, it begins its growth afresh, and in each jurisdiction its development has been different. No lawyer from Texas, Arkansas, North Carolina, Louisiana or Connecticut, for example, would find himself at home in a jury trial in any other of these states. Yet the history of jury trial is everywhere the same-a constant struggle on the one hand to preserve the integrity of the political ideal of laymen's justice, and the equally persistent struggle on the other to subject the jury to strict control by the court. The conflict remained on uneasy though somewhat even terms as long as the trial court retained a large measure of independence, but with the development of highly integrated court systems under the complete dominion of appellate courts, both trial courts and jury have fallen under the control of the higher courts, and jury trial in current civil cases has lost most of its significance. ${ }^{1}$ This shift of power has not taken place without protest by many strong judges, and among these none has been more effective in preserving the American jury's orthodox power than has Justice Black.

\section{The Shift of Power to Appellate Courts}

Perhaps the stoutest strand of jury trial is its political significance. Its original function was in giving support to the King's administrative officials, and later to his traveling justices in their efforts to extend the jurisdiction of the King's courts throughout England. It was a big factor in the eventual ascendancy of the King's courts, for it drew to the aid of the judges the strong men of the locality, who either knew the factual background of the matters that came before the court, or could be trusted to make reliable judgments on what they learned from others. It thus afforded a more rational basis of doing justice than was

$\dagger$ Professor of Law, University of Texas.

1. The conclusions here summarized are drawn from the study and teaching of torts, procedure and related subject matters over a period of some forty years. It would be impossible to list specifically the materials from which I have drawn these conclusions. Aside from an endless procession of judicial opinions, the great studies of Wigmore, Pound, Millar, Thayer, Holdsworth, Plucknett, Sunderland, Morgan, Clark, Frank, Arnold and McCormick, and the law review writings of numerous contemporaries, have each contributed something to my impressions. And no doubt some years of trial and appellate practice have given color to them. Other attempts of the writer to depict the capture of trial court and jury by the appellate courts are found in GREEN, JUDGE AND JURY c. 14 (1930); Green, Blindfolding the Jury, 33 TExas L. Rev. 158, 273 (1954-55); Green, The Individual's Protection Under Negligence Law, 47 Nw. U.L. REv. 751 (1953). 
provided by the cruder methods of trial that it supplanted. Even so, the beginning of jury trial was timid, and it passed only haltingly from assize and inquisition to fact determination based on the testimony of witnesses, and the application of the law as given by the judge to the facts so found.

Jury trial everywhere has been a process of rough justice, never subject successfully to great refinement, and always capable of great abuse. There has never been a period when it was not ripe for reform. Its success has been in honest approximation; its best services in the frontier periods of English and American societies-in criminal cases, in land suits, in actions for debt, in civil actions involving physical violence, in the simpler cases of fraud and in both civil and criminal cases involving political rights. In all these cases, it has saved trial judges difficult and embarrassing judgments and with rare exceptions has won and held their affections.

To citizens generally, jury trial has given a sense of political freedom; a feeling of being a part of government. It offers an assurance of judgment by neighbors who understand the community climate of values, a bulwark against the petty tyrannies of headstrong judges, and a means of softening the cold letter of the law in cases of hardship. As political, social and economic environments have changed, jury trial has changed its character also. But even so, these historic memories are still retained, and "we the people" insist on its retention, if for nothing more than as a symbol of political freedom, emphasizing the dignity of the citizen and the power of the local community. Moreover, the trial judge still finds in jury verdicts relief from making embarrassing judgments and protection against the criticism that arises from an unpopular outcome of a trial. And so we may dismiss the suggestion that jury trial will be expurgated from our law. Even though it may become only a formalism, it is probably an enduring watermark of the common law.

Another stout strand of jury trial is its function of determining disputed "issues of fact" in civil cases. It has never been easy for courts to make use of juries in the determination of law suits. No one has yet been able to isolate issues of fact and issues of law and keep them isolated for purposes of judgment, and it is even more difficult to hold a jury within the limits of their function without on the one hand restricting their power so that they cannot perform intelligently, or on the other hand surrendering the whole case to the jury. And it is perhaps equally difficult to restrain the judge within the limits of his functions. The attempt to maintain a workable equilibrium of the dual agency of judge and jury is a long and intricate story which can only be swiftly summarized here.

As long as civil cases remained simple, and the issues were in the domain of the understanding of everyday citizens, jury trial both in England and in this country was relatively satisfactory. But as civil cases became more complex and litigation brought within its vortex the interests of an expanding commercial and industrial economy; as the significance of these interests outran the understanding of laymen; as population multiplied and became mobile, so that strangers infiltrated every precinct; as business activities became or- 
ganized into great enterprises that overflowed their local and even state boundaries; as many activities came to depend on dangerous machines that counted their victims by the thousands; as insurance companies assumed liability and took over the role of defense; as the experts and their methods in all the fields of science were called upon to supply proof; and as the courts through which the swelling tides of litigation were channelled grew in number and overlapped in jurisdiction, many serious conflicts have arisen within the jury process. Furthermore, selection of jurors on the basis of property, moral and educational qualifications, and conversely, exemption of many of the best citizens from jury service; tampering with jurors and their own misconduct; suits between local citizens and those foreign to the community, especially where the stranger was a corporation; suits between servants and their corporate masters; suits between the wealthy and the poor; suits between landowners and their tenants; suits between the ethical lawyer and the one not so ethical-these and a hundred other conflicts brought extraneous influences to bear on the jury's determination of the issues between the parties to the suit.

As these problems arose, they were met by the judges, sometimes assisted by the legislatures, with practices devised primarily for use by the trial judge. Among the most important, perhaps, were the early attaint of the jury for false verdict; the special verdict in all of its variations; refinement of the pleadings through demurrers, motions and replies, so that only a single issue remained for trial if it could not be resolved as a matter of law ; judgments notwithstanding the verdict; nonsuits; directed verdicts; new trial; change of venue; remittance of damages; rules for excluding, restricting or testing the testimony of witnesses and other data for admission in evidence; detailed instructions to the jury on the law, sometimes accompanied by comment on the facts; and many other practices of lesser importance. Each of these practices originated in some environment that was thought to call for control of the jury; each has an extended history all its own.

Even with these strong measures in the hands of the trial judge, jury determination of issues has never been highly dependable. Moreover, changes in the trial process and at other points have frequently thrown control out of kilter. Serious and lasting maladjustments have resulted from the great reforms which liberalized and expanded the litigation process so as to combine matters of law and equity, and to permit the extensive joinder of causes of action and parties, with the corresponding multiplication of defensive issues, impleading of third parties, cross-actions and counterclaims ad infinitum. This heavy loading of a single litigation so as to constitute a mass trial of issues has imposed tremendous burdens on jury trial. Trials are extended in time, instructions are lengthy and involved, and the opportunities for error are almost limitless. Verdicts that cannot be sustained call for new trials or provide the basis for appeals. New rules for the submission of issues, for making and preserving exceptions and for assigning errors; doctrines of harmless error; and scores of other correctional devices do not remove the burdens or supply the antidotes for the complexities injected into the trial by these reforms from which so much was expected. 
The greatest relief for the trial courts has in fact come by the transfer of the burden of responsibility to the appellate courts, and the appellate courts, in self-defense as it were, have been compelled to evolve themselves from mere courts for pointing out errors of law into courts of comprehensive review for the authoritative determination of the law, and in many instances of the facts as well. To say that this transfer in responsibility gave relief to the judicial system would be inaccurate. Instead it has required tremendous expansion of the system and has produced a mass of judicial decision which in itself consitutes a formidable problem for both practitioners and trial courts.

Let us examine this development a little more closely. The increased comple:sity in trials and the comprehensive review on the facts as well as the law by the appellate courts have imposed a great burden on the whole court system. The trial judge's attempts to instruct the jury on a multitude of issues within the limitations of increasing doctrinal refinements, and at the same time to leave the jury free to exercise their functions, are seldom faultless. Not only must the trial courts themselves frequently grant new trial, but many cases are transferred to the appellate courts to be unscrambled and sent back for another trial. There has been no speeding and simplifying of the disposition of cases; rather, the dockets in both trial and appellate courts of heavily populated areas are becoming ever more crowded. It is not unusual for a case to be before a court from four to six times. More judges, both trial and appellate, are required; then more courts, both trial and appellate; then more trial procedures and more appellate procedures; then more authoritative declarations by the appellate courts on points of procedural and substantive law in order to bring uniformity in practice, and certainty in the law. Then in order to protect their reviewing processes, the appellate courts must declare the law with the utmost meticulousness so that the trial courts can make it effective in ruling on motions and in their instructions to juries.

$\therefore$ remarkable development has taken place at this point. In tort cases for example, the courts at first used general expressions as "reasonable care," "the urdinary prudent man," "under all the surrounding circumstances" and like phrases as guiding lights for jurors. The issues were simple: negligence, contributory negligence, last clear chance, causal relation and damages were the usual inquires for jury findings. On the basis of these issues and guiding lights the judges in many jurisdictions summarized the facts, and in some commented in the weight of the evidence. The lawyers however though this gave the trial judge too much power over the jury and as a result of their pressure in most states, either by statute or constitution, comment on the evidence in any form was prohibited.

The courts could not and did not accept this defeat and surrender of power. They yerformed an exceedingly clever manetuer. In order not to offend the rule against comment on the weight of evidence, they simply transmuted specific circumstances into questions of law, which of course are the raw materials out of which rules of law are formulated. With these rules the trial judge himself could pass judgment on many details and restrict the jury's 
judgment on others. Of more importance, the appellate courts were enabled to check his judgments at every step. Good examples of what has been done are found in the landowner categories of trespasser, licensee and invitee; in the extensive network of causes-proximate, remote, sole, intervening and supervening; and in the multitude of specific rules involving presumptions, burden of proof, res ipsa loquitur, negligence per se, unavoidable accident and a host of other doctrinal gadgets.

Thus the appellate courts have steadily moved in on the jury's province of determining whether "under all the circumstances" the defendant was negligent, the plaintiff was contributorily negligent, or the defendant had the last clear chance, and whether the conduct involved contributed to the plaintiff's injury - by creating rules of law designed to control the jury's consideration of every circumstance in a litigation. This process has so bloated these simple issues that it is not unusual for the court to have to pass upon a multitude of sub-issues in order to determine a single basic inquiry in a case. So it is that principles, theories, doctrines, rules and formulas of law, procedural and substantive, have been spun and refined without limit; and there seems to be no way to bring to an end this upward-spiralling process of lawmaking and lawrefining. To say that neither trial judge nor jury can successfully respond through general instructions or special issues to a process so extravagantly developed for remote control by appellate courts, is an understatement for which I can only apologize.

It can be said with assurance that the appellate courts have now secured control of all the essentials of jury trial. The trial judge is not much more than a trial examiner, while the jury simply satisfies the public and professional craving for ceremonial-the necessity for dealing with simple matters as though they were freighted with great significance. Fortunately, most cases end in some fashion with the trial determination; otherwise the judicial process would not work at all. But in any case in which either party wishes appellate review, and has been forehanded enough to make a record, the judgment of the trial court is subject to the judgment of the appellate court on the law, and on the facts as well, if the appellate court chooses to exercise its control.

Trial by record before an appellate court, even assuming an accurate record and conscientious review, has little resemblance to jury trial as it had developed in Anglo-American judicial history. It is thus that the significance of jury trial in civil cases has become so largely that of a symbol. The more trial by record is developed, the more jury trial comes to have merely symbolic value. Nor does trial by record serve the cause of justice to a greater advantage than jury trial; trial by record has its dangers, also. It is rare that the "fall out" in jury trial does not pollute a record with error. Moreover, the trial may be recorded with the utmost fidelity, but many of its overtones and undertones do not find their way into the record. In the trial court the case is pulsing with life; by the time it reaches the appellate court, much of its life has leaked out or evaporated. Again, the objectives of the two courts are somewhat different. In the trial court the emphasis is on justice as between the parties; in 
the appellate court it is on keeping the lines of the law straight and systematic for justice in general. This change in emphasis may make a great deal of difference in a close case. It is only with the utmost effort, if at all, that even the most able and patient appellate judge can bring a case back to life. And not only has the case lost its vitality, it has taken on new elements which may affect its disposition: new personalities; inadequate briefs, perhaps; restatement and reinterpretation of the facts and the law; the wider administrative outlook from the appellate bench; and a multitude of what are thought of as purely incidental influences-subtle influences-which nevertheless take their toll. Passing on the merits of a close case at long range in time and distance and in a hushed environment is a delicate undertaking. Under the subtle attacks of masterful advocates the rulings of a trial court can frequently be made to appear wrong, unfair, or even grotesque. If the appellate court is so convinced, its judicial conscience drives it to exercise some control to nullify what looks from afar like a bad result. Unless the judge handling the case is a dullard (and this is so rare that it need not be taken into account), some device of appellate control-even resort to "the manifest weight of the evidence"-is always at hand to further the ends of justice as they may appear, however perfect the record may seem on its face.

This is not an unnatural development in any hierarchy. It has required a century to develop the current court systems of the states and the nation into well-articulated hierarchies. And as the development has advanced, the importance of jury trial and the trial judge has declined. This may or may not be unfortunate. I do not know enough to be certain one way or the other. But what has happened here as a result of the concentration of controls and power in the appellate courts is not an isolated phenomenon in our culture. The same development may be observed in the strong group controls that have resulted from the exodus from the farms to the towns and cities; the drying up of the country newspaper by the city newspaper; the mergers in turn of city newspapers under a single management, and finally the consolidation of newspaper, radio and television into chains under the domination of a relatively small group of owners and advertisers. Our thinking and culture in many of their important aspects tend steadily to fall under the control of a few public relations firms in our larger cities. And in fact, we observe like movements in all the important economic and governmental affairs of our time.

All this may be an inevitable product of the American genius for organization and the concentration of power. Whatever its ultimate explanation, the shift of power from the trial court and jury to the appellate court-from the local community to a centralized court system-may well deaden the administration of the law, just as these other concentrations of power have produced conformity in other facets of our lives. Perhaps these developments cannot and should not be stopped. Perhaps the only escape from the excessive expense, delays, procedures and refinements of law incident to jury trial is by shifting more and more power to the appellate courts. The open recognition of their power and responsibility might be an exceedingly wholesome influence 
in the administration of justice. But if jury trial is to be preserved in civil cases as anything more than a sort of preliminary examination merely formulating the decisive issues for the appellate courts, heroic measures are required to bring about a realignment of the judicial process. ${ }^{2}$

\section{The Supreme Court and Jury Trial}

Efforts have been made to counteract this trend in at least one small area of the law; their results can be seen in the more recent cases decided by the United States Supreme Court under the Federal Employers' Liability Act. ${ }^{3}$ For a period at least the Court has attempted to free this litigation from the strangling doctrinal controls developed by common law appellate courts. This has not always been the attitude of the Court in FELA cases ; the about-face began about the time Justice Black came on the Court. From that time until quite recently, writs of certiorari have been granted frequently, and the opinions written by the majority have for the most part accorded the jury its orthodo: functions in tort litigation. 5

As has been frequently observed, the original FELA was given meaning by common law lawyers in the spirit and often in the terms of common law doctrines. Contributory negligence having been denied by the Act as a defense

2. First. In personal injury and death actions, comparative negligence is an essential formula for effective jury trial. Comparative negligence is more compatible with the common sense of the jury than the "all or nothing" attitude of common law doctrines.

Second. The real parties in interest should be brought out in the open in all litigation.

Third. The submission of cases to the jury should be upon special issues, as in North Carolina and the English jurisdictions, and as now permitted under the federal rulcs, where a few vital issues are stated in the form of questions easily comprehended by jurors, and supported by clear instructions as to the relevant legal rules.

Fourth. The dignity and power of the trial judge should be restored. The trial judge is the key official in the judicial process. The center of gravity should rest in the trial bench. Good trial judges with adequate power would be enabled to reduce greatly the work of the appellate courts and the time and expense of litigation.

Fifth. Rather than review of records by appellate courts there should be prompt local hearings by a panel of judges whose function should be to determine whether substantial justice has been done, and, if not, to correct the injustice. The appellate courts should restrict review to cases involving questions of statutory and constitutional interpretation, questions of jurisprudential policy, and matters of due process. Helpful supervision of the administration of the trial courts would be far more valuable than all the laborious attcmpts to discover refinements with which to patch the flaws found in legal doctrines and in their application to particular cases. As the supreme authority over the operations of the judicial process, appellate judges should find their greatest satisfaction in developing successful administration of the law in the trial courts.

3. 35 STat. 65 (1908), as amended, 45 U.S.C. $\$ \$ 51-60$ (1952).

4. See New York Cent. R.R. v. Ambrose, 280 U.S. 486 (1930); Missouri Pac. R.R. v. Aeby, 275 U.S. 426 (1928) ; Chicago M. \& St. P. Ry. v. Coogan, 271 U.S. 472 (1926). See also discussion by Justice Black in Tiller v. Atlantic Coast Line R.R., 318 U.S. 54 (1943); Wilkerson v. McCarthy, 336 U.S. 53, 68 (1949) (concurring opinion per Douglas, J.).

5. See appendix to concurring opinion of Justice Douglas in Wilkerson v. MeCarths, supra note 4 , at 71 . 
other than in diminution of damages, it was not difficult for the courts to convert contributory negligence into assumption of risk, and thereby interpose a complete defense to the action. ${ }^{\circ}$ When assumption of risk was eliminated as a defense by the 1939 amendment to the Act, ${ }^{7}$ it was not difficult to convert the defense of contributory negligence or assumption of risk into the defense of no evidence of any negligence on the part of defendant, ${ }^{8}$ or that his negligence was not the proximate cause of plaintiff's injury, ${ }^{0}$ or that plaintiff's own negligence was the sole proximate cause of his injury. ${ }^{10}$ It was this type of avoidance that Justice Black met head on, and with the support of a majority of the Court put an end to, at least for a time.

In Tiller v. Atlantic Coast Line R.R., ${ }^{11}$ Justice Black struck his hardest and most effective blow against the doctrine that had been employed to give the courts, both trial and appellate, practically complete control over FELA litigation and to render jury trial of little importance. The lower courts had undertaken to distinguish between assumption of risk resulting from the employer's negligence and assumption of risk incident to the employment in the absence of negligence by the employer. As observed in the concurring opinion of Justice Frankfurter there is a distinction, but the distinction is ambiguous and confusing, and should be discarded. ${ }^{12}$ Justice Black did his best to get rid of it. He said:

"We hold that every vestige of the doctrine of assumption of risk was obliterated from the law by the 1939 amendment, and that Congress, by abolishing the defense of assumption of risk in that statute, did not mean to leave open the identical defense for the master by changing its name to 'non-negligence.' "13

This case was quickly followed by Bailey $v$. Central Vermont $R y .{ }^{14}$ in which it had been held by the Vermont Supreme Court that the evidence was insuffi(1943).

6. See discussion by Justice Black in Tiller v. Atlantic Coast Line R.R., 318 U.S. 54

7. 53 Stat. 1404 (1939), 45 U.S.C. $\$ 54$ (1952).

8. DeZon v. American President Lines, Ltd., 318 U.S. 661 (1943). In his dissent in this case Justice Black protested: "When we consider the weight of the evidence and resolve doubtful questions such as these, we invade the historic jury function." Id. at 674. In his dissent in Stewart v. Southern Ry., 315 U.S. 283, 287 (1942), Justice Black said: "Respect for the institution of trial by jury should, in my judgment, prompt us to leave undisturbed the jury's finding in this case that the coupler was defective. Because it must rely on the written page rather than living words, an appellate court can never fully appreciate the effect of testimony heard by a jury of local citizens." Ibid. See also Moore v. Chesapeake \& O. Ky., 340 U.S. 573 (1951) ; Eckenrode v. Pennsylvania R.R., 335 U.S. 329 (1948).

9. Reynolds v. Atlantic Coast Line R.R., 336 U.S. 207 (1949); Lavender v. Kurn, 327 U.S. 645 (1946) ; Tennant v. Peoria \& Pekin Union Ry., 321. U.S. 29 (1944) ; Brady v. Southern Ry., 320 U.S. 476 (1943).

10. Brown v. Western Ry., 338 U.S. 294 (1949) ; Wilkerson v. McCarthy, 336 U.S. 53 (1949).
11. 318 U.S. 54 (1943).
12. Id. at 68 .
13. Id. at 58 .
14. 319 U.S. 350 (1943). 
cient to raise an issue of defendant's negligence, even though a jury had found negligence. The Supreme Court through Justice Douglas reversed, holding that an issue had been raised. ${ }^{15}$ Shortly thereafter, in Tennant $v$. Peoria $\mathcal{E}$ Pekin Union $R y .,{ }^{16}$ the issue was whether the death of deceased resulted from the negligence of the defendant in failing to give warning of the movement of a train. The trial court's judgment based on a jury verdict had been set aside by the circuit court of appeals. The opinion was given by Justice Murphy, who said in part:
"It is not the function of a court to search the record for conflicting circumstantial evidence in order to take the case away from the jury on a theory that the proof gives equal support to inconsistent and uncertain inferences. The focal point of judicial review is the reasonableness of the particular inference or conclusion drawn by the jury. It is the jury, not the court, which is the fact-finding body. It weighs the contradictory evi- dence and inferences, judges the credibility of witnesses, receives expert instructions, and draws the ultimate conclusion as to the facts. The very essence of its function is to select from among conflicting inferences and conclusions that which it considers most reasonable . . . That conclusion, whether it relates to negligence, causation or any other factual matter, cannot be ignored. Courts are not free to reweigh the evidence and set aside the jury verdict merely because the jury could have drawn different inferences or conclusions or because judges feel that other results are more reasonable."17

Here in three closely related decisions, each with its dissents, the pattern of jury trial was restored to a determination of the three basic issues of a tort case-negligence of the defendant, causal relation between the defendant's negligent conduct and the injury, and the amount of damages-each a jury question if there is any basis for reasonable minds to differ in reaching a conclusion on the issue. It may be observed in passing that the "proximate cause" issue in this and other cases under the statute is restricted to causal relation "in whole or in part."18 The endless and useless confusion developed by many of the common law courts about the term "proximate cause" is sedulously avoided. ${ }^{19}$

15. See also Stone v. New York, C. \& St. L.R.R., 344 U.S. 497 (1953) ; Willis v. Union Pac. R.R., 329 U.S. 649 (1947) ; Jesionowski v. Boston \& M.R.R., 329 U.S. 452 (1947).

16. 321 U.S. 29 (1944).

17. Id. at 35. See also Lavender v. Kurn, 327 U.S. 645 (1946). Judge Jerome Franl: dissenting in Cahill v. New York, N.H. \& H.R.R., 224 F.2d 637, 640 (2d Cir. 1955), said: "I assume, arguendo, that the inference needed to support the verdict would not suffice in a suit not brought under the Federal Employers' Liability Act. But the more recent Supreme Court decisions make it clear that, under that Act, the jury's power to draw inferences is greater than in common-law actions."

There would seem to be no justification for this attitude. It merely reflects how far the courts have gone in other areas of litigation in restricting, if not denying, the jury's orthodox common law function to draw inferences.

18. 45 U.S.C. $\$ 51(1952)$.

19. See the excellent discussion of the term by Justice Frankfurter in his dissent in Standard Oil Co. v. United States, 340 U.S. 54, 66 (1950). See also Coray v. Southern 
In other respects as well Justice Black and his associates have protected the right of jury trial under the FELA and supporting acts from attrition. In Duncan v. Thompson ${ }^{20}$ an employee had accepted an advance of $\$ 600$ from the defendant on condition that if a settlement could not be reached and the employee brought suit he must first return the $\$ 600$. He brought suit without doing so. Meeting the defense based on the agreement, Justice Black reversed the Missouri court and held the agreement void under section 5 of the Act as a method of exempting defendant from liability. ${ }^{21} \mathrm{He}$ failed in his attempt to eliminate the defense of assumption of risk under the "free pass" agreement, ${ }^{22}$ but more recently he and his colleagues invalidated a contract restricting the choice of venue for an action based upon the FELA. ${ }^{23}$

Justice Black has been equally vigorous in protecting jury trial from doctrinal limitations that the state courts have sought to impose. In Garrett $v$. Moore-AICCormack Co., ${ }^{24}$ he rejected the Pennsylvania rule that the burden of proof was on the employee to show by "clear, precise and indubitable" evidence that a release from liability executed by the defendant and accepted by the employee was invalid. Much later, in a somewhat similar case, ${ }^{25}$ he likewise rejected an Ohio practice under which the invalidity of a release was required to be found by the judge as in equity by "clear, unequivocal and convincing evidence." He stated the matter simply:

"We have previously held that "The right to trial by jury is a basic and fundamental feature of our system of federal jurisprudence' and that it is 'part and parcel of the remedy afforded railroad workers under the Employers' Liability Act' . . . . It follows that the right to trial by jury is too substantial a part of the rights accorded by the Act to permit it to be classified as a mere 'local rule of procedure' for denial in the manner that Ohio has here used. ... The trial judge and the Ohio Supreme Court erred in holding that petitioner's rights were to be determined by Ohio law and in taking away petitioner's verdict when the issues of fraud had been submitted to the jury on conflicting evidence and determined in petitioner's favor." 20

Pac. R.R., 335 U.S. 520 (1949) ; Anderson v. Atchison, T. \& S.F. Ry., 333 U.S. 821 (1948) ; Brady v. Southern Ry., 320 U.S. 476, 484 (1943) (dissenting opinion); Note, 31 N.C.L. REv. 216 (1953).

20. 315 U.S. 1 (1941).

21. In an entirely different environment, Justice Black was successful in striking down an attempted exemption of a towboat owner from liability for negligence resulting in damage to a barge that was being towed. Bisso v. Inland Waterways Corp., 349 U.S. 85 (1955); Boston Metals Co. v. The Winding Gulf, 349 U.S. 122 (1955). Likewise, in Hughes v. Fetter, 341. U.S. 609 (1951), his opinion broke the back of state statutes denying actions in local courts for wrongful deaths occurring outside the local jurisdiction.

22. Francis v. Southern Pac. R.R., 333 U.S. 445, 451 (1948) (dissenting opinion).

23. Boyd v. Grand Trunk Western R.R., 338 U.S. 263 (1949), reversing per curiam, 321 Mich. 693, 33 N.W.2d 120 (1948).

24. 317 U.S. 239 (1942).

25. Dice v. Akron, C. \& Y.R.R., 342 U.S. 359 (1952).

26. Id. at 363 . 
In Brown $v$. Western $R y^{27}$ the Georgia court had sustained a demurrer to plaintiff's complaint under a rule requiring allegations to be construed "most strongly against the pleader." In sending the case back for trial Justice Black said in part:

"It is contended that this construction of the complaint is binding on us. The argument is that while state courts are without power to detract from 'substantive rights' granted by Congress in FELA cases, they are free to follow their own rules of 'practice' and 'procedure.' To what extent rules of practice and procedure may themselves dig into 'substantive rights' is a troublesome question at best as is shown in the very case on which respondent relies....

"Here the Georgia court has decided as a matter of law that no inference of railroad negligence could be drawn from the facts alleged in this case. Rather the court itself has drawn from the pleadings the reverse inference that the sole proximate cause of petitioner's injury was his own negligence. Throughout its opinion the appellate court clearly reveals a preoccupation with what it deemed to be petitioner's failure to take proper precautions. ... Strict local rules of pleading cannot be used to impose unnecessary burdens upon rights of recovery authorized by federal laws. ... [S] hould this Court fail to protect federally created rights from dismissal because of over-exacting local requirements for meticulous pleadings, desirable uniformity in adjudication of federally created rights could not be achieved."2s

In nearly all the cases in which the pattern of trial in FELA cases was developed by Justice Black and the majority of the Court there were vigorous dissents. One of the arguments urged by the dissenters was that the writs of certiorari in such cases were improvidently granted; the Court had more important business than keeping the common law doctrines of negligence aligned for so many state and federal courts and it was entirely too burdensome for the Court to be compelled to canvass the record for errors in the application of such doctrines where application depended so greatly on the judgment of the particular court. Justice Frankfurter put the point sharply in his dissenting opinion in Stone v. New York, Chicago \& St. Louis R.R. :29

27. 338 U.S. 294 (1949).

28. Id. at $296,298-99$.

In another context Justice Black has carried his concern for the trial court's integrity and its freedom from the overlordship of the appellate court to an extreme that many critics consider wholly unjustifiable. The point involved is the construction of $F_{E D}$. R. Crv. P. 50(b) so as to forbid the entry of a judgment n.o.v. by the appellate court in absence of a motion to that end duly presented to and passed upon by the trial court. The matter came to a crux in Johnson v. New York, N.H. \& H.R.R., 344 U.S. 48 (1952), where the failure to make the motion in the trial court seems a trivial procedural technicality indeed. But in view of the note appended by Justice Black as to the practice in the Second Circuit the point is not as flimsy as it would otherwise seem, and if not insisted upon it could well have widened a breach in the practice which would have materially broadened the appellate power. Id. at $54 \mathrm{n} .3$. This is not to argue that the appeliate court should not have the power, but merely to emphasize the devotion of Justice Black to the cause of the trial court's integrity, and his consistency in guarding it from further inroads. But sce Justice Frankfurter's sharp dissent, id. at 54; see also Clark, Code Pleading 71 (2d ed. 1947).

29. 344 U.S. 407 (1953). 
"When it thus put the enforcement of the law in the keeping of State courts, the Congress knew that the determination of whether there is adequate evidence to sustain a claim of negligence is one of the most elusive determinations that judges are called upon to make."30

Another argument, stressed especially by Justice Frankfurter, is that the concept of negligence as a working principle for modern industry is outmoded and should be replaced by the principle of insurance that underlies workmen's compensation laws. ${ }^{31}$ Apparently his idea is that by refusing to take cognizance of the maladministration of FELA cases the Supreme Court will prompt Congress to provide a better remedy more quickly.

These arguments are not without weight. The Supreme Court of the United States is a public law court. ${ }^{32}$ Perhaps little justification can be found for imposing upon it the supervisory administration of the tort litigation arising under the several acts providing protection for workmen engaged in interstate and foreign commerce against physical injuries and death. But until arrangement can be made for supervision by some other court, or for some more adequate form of protection, ${ }^{33}$ it is unthinkable that the protective acts of Congress thall be left to the administration of some sixty separate far-flung systems of state and intermediate appellate federal courts with their differing doctrinal networks of negligence law and their divergent attitudes towards the purposes

30. Id. at 412. See also Dice v. Akron, C. \& Y.R.R., 342 U.S. 359, 364 (1951) (dissenting opinion); Wilkerson v. MeCarthy, 336 U.S. 53, 64 (1949) (concurring opinion); Bailey v. Central Vermont Ry., 319 U.S. 350, 354 (1943) (dissenting opinion).

31. Carter v. Atlanta \& St. A.B. Ry., 338 U.S. 430, 437-38 (1949): "To apply the' concepts of 'nesligence' and 'proximate cause' to the infinite complexities of modern industry is like catching butterflies without a net."

32. Currently little common law tort litigation comes before the Court. A few recent cases, hovever, indicate Justice Black's keen understanding of common law tort theory. His dissent in United States v. Causby, 328 U.S. 256, 268 (1946) (damage to respondent's chicken farm by low-flying government planes held to be an unconstitutional taking of private property) is most compelling, and its rejection can be accounted for only by the absence at that time of a Federal Tort Claims Act. Likewise the dissent of Justice Jackson (joined by Justice Black) in Dalehite v. United States, 3.6 U.S. 15, 47 (1953) (government held not liable under the Tort Claims Act for the Texas City disaster) seems so conclusive in its reasoning that it is difficult to account for the decision except on the ground that the majority was staggered by the exaggerated liabilities presented by the claimants. Justice Elack's position in United States v. Standard Oil Co., 332 U.S. 301 (1947) (government cannot sue in tort for injuries to soldier in the absence of congressional authorization) was a surprise to many observers. The reasons given by the majority with whom he joined are distressingly flimsy. The Court may have felt that because the government could not be sued in tort at that time, its power to sue a private person should not be enlarged. It may also be that the Court considered this a good case to show that it was after all a conservative Court; that it was no longer the bad old New Deal Court that had taken so much criticism.

33. Cf. Richter and Forer, Federal Employers' Liability Act-A Real Compensatory Law for Railroad Workcrs, 36 CoRNell L.Q. 203 (1951) ; Pollack, Workmen's Compensation for Failroad Work Injuries and Diseases, $36 \mathrm{id}$. at 236. 
of the acts. ${ }^{34}$ In the attempt to set a pattern simple in design, orthodox in theory, and easy of administration by trial courts, Justice Black and his colleagues of the majority have achieved at least a momentary success. ${ }^{35}$ But nothing less than constant vigilance on the part of the Court can prevent a resurgence of appellate domination of the jury's function in the administration of the acts. ${ }^{36}$

34. See, e.g., Atlantic Coast Iine R.R. v. Anderson, 221 F.2d 548 (5th Cir. 1955); Wetherbee v. Elgin, J. \& E. Ry., 204 F.2d 755 (7th Cir. 1953) ; Gill v. Pennsylvania R.R., 201. F.2d 718 (3d Cir. 1953) ; Walker v. Lykes S.S. Co., 193 F.2d 772 (2d Cir. 1952), 62 YALE L.J. 111. The administration of the state courts is even more erratic.

35. Fortunately there are other devoted guardians of jury trial and of the integrity of trial courts to be found in the state and federal systems. Outstanding among these is Justice Carter of the California Supreme Court, whose opinions are probably unequaled for their sturdy advocacy of jury trial. And the scholarly and articulate Judge Jerome Frank of the Second Circuit, although he would like to see jury trial eliminated by constitutional amendment, at least in civil cases, never ceases to urge the overwhelming importance of the facts in every litigation, and the exclusive power of the jury, under existing constitutional provisions, to evaluate the facts. Skidmore v. Baltimore \& O.R.R., 167 F.2d 54 (2d Cir. 1948) ; United States v. Antonelli Fireworks Co., 155 F.2d 631, 665 (2d Cir. 1946). But such judges are rare and they may well be the last great judges who intelligently fight the battle for the jury. For the power of organization, the volume and haste of the flow of business, and the mesh of doctrine are steadily and remorselessly taking jury trial (except for the formality) out of play as a mechanism for the protection of the individual's rights in civil matters.

36. It will be observed how the recently improved doctrine of forum non conveniens, 62 STAT. 937 (1948), 28 U.S.C. \$ 1404(a) (1952), is already upsetting the equilibrium of litigation under the FELA. As a delaying tactic it has few equals; as a control of jury trial its significance is unfathomable. See Norwood v. Kirkpatrick, 349 U.S. 29 (1955); Missouri ex rel. So. Ry. v. Mayfield, 340 U.S. 1 (1950); Richter \& Forer, Proposed Changes in the Lazes Governing Injuries in Interstate Transportation, $67 \mathrm{HARv}$. L. REv. 1003, 1012 (1954) ; Comments, 29 Ind. L.J. 97 (1953), 52 Mich. L. Rev. 1211, 39 Minn. L. Rev. 115 (1954). 